\title{
Pengaruh E-Learning dengan Google Classroom terhadap Hasil dan Motivasi Belajar Biologi Siswa
}

\author{
Rikizaputra $^{1]}$, Hanna Sulastri ${ }^{2]}$ \\ Universitas Lancang Kuning \\ E-mail: ${ }^{1]}$ rikizaputra@unilak.ac.id \\ ${ }^{2]}$ sulastrihanna@gmail.com
}

\begin{abstract}
Abstrak
Kemajuan ilmu pengetahuan dan teknologi informasi telah membawa dampak positif bagi kemajuan pendidikan salah satunya dengan adanya e-learning. Penelitian ini bertujuan untuk mengetahui pengaruh pembelajaran berbasis e-Learning terhadap hasil belajar dan motivasi belajar siswa pada materi sistem pencernaan. Penelitian ini dilaksanakan pada bulan Januari 2020 di XI MIA SMA Nurul Falah Pekanbaru. Penelitian ini merupakan kuasi eksperimen dengan menggunakan the matching only pretest posttest control group design. Teknik pengambilan sampel dilakukan dengan menggunakan sampel jenuh. Sampel penelitian di kelas eksperimen sebanyak 21 orang siswa dan kelas control sebanyak 20 orang siswa. Intrumen tes berupa soal pilihan ganda, angket motivasi belajar dan lembar observasi merupakan instrumen pengambilan data yang digunakan. Data penelitian dianalisis menggunakan Independent 2 samples t-tes. Hasil penelitian menunjukkan bahawa rerata $N$-Gain kelas eksperimen sebesar 0,612 dan rerata pada kelas control adalah 0,486 sedangkan rerata $N$-Gain motivasi belajar pada kelas eksperimen sebesar 0,39 dan pada kelas kontrol hanya 0,27 . Terdapat perbedaan yang signifikan antara kelas eksperimen dan kelas control dari uji t yang dilakukan. Berdasarkan data ini maka dapat disimpulkan bahwa terdapat pengaruh e-learning dengan google clasroom terhadap hasil belajar dan motivasi belajar siswa kelas XI MIA SMA Nurul Falah Pekanbaru pada materi Sistem Pencernaan.
\end{abstract}

Kata Kunci: E-Learning, Google Classroom, Hasil dan Motivasi Belajar Biologi

The Effect of E-Learning with Google Classroom to the Learning Student Result and Student's Motivation on Biology

\begin{abstract}
The advancement of science and information technology has brought a positive impact on the progress of education one of which is by e-learning. This study aims to determine the effect of e-Learning based learning on student learning outcomes and learning motivation on the digestive system material. This research was conducted in January 2020 at XI MIA Senior High School Nurul Falah Pekanbaru. This research is a quasi-experimental using the matching only pretest posttest control group design. The sampling technique is done by using saturated samples. Research samples in the experimental class were 21 students and the control class were 20 students. Test instruments in the form of multiple choice
\end{abstract}


questions, learning motivation questionnaires and observation sheets are the data collection instruments used. The research data was analyzed using Independent 2 samples $t$-test. The results showed that the average $N$-Gain of the experimental class was 0.612 and the mean of the control class was 0.486 while the average $N$-Gain of learning motivation in the experimental class was 0.39 and the control class was only 0.27. Based on the results of the t-test it is known that there are significant differences between the experimental class and the control class. Based on this data, it can be concluded that there is an influence of e-learning with Google Classroom on learning outcomes and learning motivation of students of class XI MIA Nurul Falah Pekanbaru High School on Digestive System.

Keywords: E-learning, google classroom, student learning result, student motivation

\section{PENDAHULUAN}

Dalam kehidupan manusia pendidikan memberikan peran yang sangat penting. Seseorang memiliki kecerdasan intelektual, sikap yang baik dan keterampilan yang memberi manfaat dikemudian hari baik bagi dirinya sendiri maupun lingkungan sekitar dengan adanya pendidikan.

Pendidikan salah satunya bertujuan untuk menyelenggarakan kegiatan pembelajaran. Dimyati \& Mudjiono (2013) menyatakan bahwa belajar adalah proses dua arah, sehingga siswa memerlukan umpan balik dari guru demikian pula sebaliknya agar pembelajaran berlangsung efektif. Terjadinya perubahan tingkah laku pada diri siswa kearah yang lebih baik, ini memnandakan bahwa siswa tersebut sudah belajar. Aspek kognitif, afektif, dan psikomotorik merupakan tiga aspek yang dapat diamati perubahannya setelah belajar (Suprijono, 2013).

Tujuan pendidikan dapat tercapai apabila pelaksanaan kegiatan pembelajaran dikelas berhasil dilaksanakan. Pelaksanaan pembelajaran di kelas hendaknya menggunakan metode yang bervariasi pada setiap mata pelajaran berdasarkan karateristik materi ajar dan siswa yang sedang belajar. Pembelajaran yang interaktif, inspiratif dan menyenangkan harus mampu dilaksanakan agar siswa termotivasi sehingga mampu berpartisipasi aktif dalam pembelajaran.

Menurut Sugihartono motivasi dalam belajar siswa dibedakan menjadi 4 golongan (Sugihartono, 2007), yaitu, motivasi instrumental, siswa belajar karena adanya dorongan berupa hadiah atau untuk menghindari hukuman. Motivasi sosial, siswa belajar oleh karena adanya dorongan untuk penyelenggaraan tugas, dalam hal ini keterlibatan siswa pada tugas menonjol. Motivasi berprestasi, siswa belajar untuk meraih prestasi atau keberhasilan yang telah ditetapkan. Motivasi instrinsik, siswa belajar karena keinginannya sendiri.

Strategi, sumber belajar, media pembelajaran, proses evaluasi dan asesmen adalah hal yang sangat menentukan tercapai atau tidaknya tujuan belajar yang mampu memberikan pertumbuhan dan perkembangan belajar siswa (Hamalik, 2011).

IPA (sains) merupakan salah satu mata pelajaran yang dipelajari disekolah. IPA berhubungan erat dengan alam semesta. Depdiknas (2004) menyatakan bahwa dalam ilmu IPA dibahas gejala gejala alam dan faktor yang mmpengaruhinya. Biologi adalah bagian dari sains yang berperan dalam mengembangkan pengetahuan, psikomotorik, sisi afektif serta tanggung jawab yang baik pada lingkungan. Konsep fisiologis yang bersifat abstrak banyak 
ditemukan dalam biologi, materi system pencernaan adalah satu diantaranya. Pemahaman sangat diperlukan dalam mempelajari materi ini agar intisari materi dapat diserap oleh siswa secara efisien.

$$
\text { Hasil observasi melalui }
$$

wawancara di SMA Nurul Falah Pekanbaru, dalam proses pembelajaran biologi terdapat beberapa kendala yang dihadapi siswa sehingga menyebabkan kurang efektifnya suatu proses pembelajaran. Rendahnya ketuntasan belajar dan kurangnya motivasi merupakan masalah yang ditemukan. Sebagian besar siswa kurang peduli dan tidak memahami dengan baik pelajaran yang sedang mereka ikuti. Siswa juga kurang memiliki persiapan untuk mengikuti pelajaran, diantaranya banyak siswa yang belum memiliki buku paket, ada siswa yang lupa membawanya, ada juga yang membawa buku tapi tidak mencoba untuk memahaminya dan tidak digunakan saat jam pelajaran berlangsung. Kurangnya keaktifan siswa dalam proses pembelajaran juga menjadi salah satu masalah dikelas, hal ini ditunjukkan oleh kurangnya tanggapan ataupun pertanyaan yang ditujukan siswa untuk guru sebagai bentuk umpan balik dalam proses pembelajaran.

Pembelajaran mandiri dengan marangkum dan menelaah materi dari berbagai sumber merupakan prinsip yang diharapkan dalam kurikulum 2013. Siswa hrus aktif dalam pembelajaran, sehingga guru yang mengajar juga dituntut untuk lebih inovatif dan kreatif. Teknologi informasi berkembang dengan sangat cepat, hal ini dapat kita lihat dari hampir seluruh siswa SMA sudah menggunakan smarthphone dalam kehidupanya. Siswa juga diperbolehkan membawa smartphone ke sekolah, tapi smartphone ini belum dimanfaatkan secara maksimal dan efisien di sekolah. Untuk itu diperlukan suatu metode pembelajaran yang sesuai dengan situasi dan masalah pelajar saat ini.
Perkembangan teknologi dari yang sederhana sampai yang canggih dimanfaatkan dalam kemajuan pendidikan saat ini. Kemajuan ilmu pengetahuan teknologi, terutama informasi teknologi membawa banyak dampak positif bagi kemajuan dunia pendidikan dewasa ini. Salah satu wujud dari pemanfaatan teknologi informasi ini adalah adanya adanya e-learning. Pada hakikatnya $E$ Learning merupakan pendekatan pembelajaran atau pembelajaran melalui pemanfaatan pendekatan teknologi komputer dan internet. Dabbagh dan Bannan-Ritland (Prawiradilaga, 2014) menyatakan bahwa konsep e-learning menggunakan fasilitas jaringan global untuk menyampaikan materi ajar serta memanfaatkannya untuk menciptakan interaksi pengajar dan peserta didik. Pembelajaran online akan meningkatkan interaksi dalam pembelajaran. Tugas perancang pembelajaran dan guru dalam pembelajaran online adalah memilih, menyesuaikan, dan menyempurnakan melalui umpan balik, penilaian, dan refleksi, kegiatan pendidikan yang memaksimalkan kemampuan web (Anderson, 2008)

Berbagai perkembangan teknologi informasi dan komunikasi menyediakan banyak sekali aplikasi learning management system (LMS) yang dapat digunakan untuk mendukung proses pembelajaran agar terasa lebih praktis dan memudahkan. Beberapa perangkat lunak yang dikembangkan adalah Moodle, Quipper, Edmodo, Google Classroom dan banyak lagi. Google Classroom merupakan aplikasi LMS yang dikembangkan oleh google yang dapat dimanfaatkan oleh guru dalam pembelajaran. Google classroom merupakan ruang kelas terstukur dalam proses pembelajaran yang ada saat ini. Aplikasi google classroom dapat di download di handphone android siswa secara gratis. Proses pembelajaran melalui 
google classroom sangat mudah dilakukan, pemberian tugaspun sangat menghemat waktu karena guru memberikan tugas tanpa kertas. Selain itu materi ajar juga masih dapat diakses walaupun siswa sudah tidak berada di kelas lagi. Berbagai kemudahab memang disajikan oleh kemajuan teknologi hari ini yang mendukung terwujudnya pembelajaran yang lebih efektif.

Hal hal yang dikemukakan di atas mnjadi latar belakang dari penelitian yang berjudul "Pengaruh e-learning dengan google classroom terhadap hasil belajar dan motivasi belajar siswa pada materi sistem pencernaan di kelas XI MIA SMA Nurul Falah Pekanbaru".

\section{METODE}

Jenis penelitian ini merupakan quasi eksperimen (quasi experimental) dengan desain the matching only pretest posttest control group yang dilaksanakan pada bulan Januari 2020 tahun ajaran 2019/2020 di kelas XI MIA SMA Nurul Falah Pekanbaru.

Seluruh siswa kelas XI MIA SMA Nurul Falah Pekanbaru yang terdiri dari kelas XI MIA 12 orang dan $\mathrm{XI}_{2}$ MIA 20 orang merupakan populasi. Sampel dalam penelitian ini diambil dengan teknik Non Probability Sampling dengan sampel yang dipilih adalah Sampling Jenuh yaitu sampel yang dipilih adalah semua anggota populasi. Kondisi ini disebabkan kaena jumlah populasi yang relative kecil (Anderson, 2010).

Data dalam penelitian ini diambil dengan menggunakan instrumen 30 butir soal tes pilihan ganda dan 20 butir angket motivasi yang mengacu pada skala likert yang sudah diujicoba kesahihan dan ketetapannya oleh para ahli.

Normalitas dan homogenitas dilakukan sebagai uji prasyarat dalam analisis data penelitian. Data yang normal dan homogen akan menggunakan uji $\mathrm{t}$ sebagai uji hipotesis. Uji hipotesis
Umann-whitney digunakan ketika data tidak normal dan homogen.

Penelitian ini menggunakan dua hipotesis yati Ho: Tidak terdapat pengaruh e-learning dengan google classroom terhadap hasil belajar dan motivasi siswa pada materi sistem pencernaan di kelas XI MIA SMA Nurul Falah Pekanbaru tahun ajaran 2019/2020. $\mathrm{H}_{1}$ : Terdapat pengaruh e-learning dengan google classroom terhadap hasil belajar dan motivasi siswa pada materi sistem perncernaan di kelas XI MIA SMA Nurul Falah Pekanbaru tahun ajaran 2019/2020.

\section{HASIL DAN PEMBAHASAN}

\section{Hasil Belajar}

\section{a. Analisis Data Pretest}

Berdasarkan data penelitian yang telah dikumpulkan maka diperoleh data pretest pada kelas kontrol dan kelas eksperimen sebagaimana yang ditunjukkan oleh gambar berikut.

Rerata
\begin{tabular}{l}
\hline \\
35 \\
Gambar 1: Rerata kelas eksperimen dan \\
kontrol
\end{tabular}
Dari Gambar 1 dapat diketahui
bahwa ada perbedaan antara pretest kelas
eksperimen dan kontrol. Eksperimen
lebih tinggi dari kontrol dengan rerata
masing-masing 32,06 dan 29,33. Selisih
nilai kedua kelas adalah 2,73. Uji
hipotesis data dilakukan setelah terlebih
dahulu dilakukan uji normalitas dan
homogenitas pada data pretest.
Kolmogorov-Smirnov (KS-21) digunakan
untuk melakukan uji normalitas dan
homogenitas data. Jika data berdistribusi
normal dan homogen maka dilanjutkan
dengan uji t. Pada uji normalitas data


pretest Nilai Asymp. Sig (2-tailed) yang diperoleh dibandingkan dengan nilai $(\alpha)$ 0,05. Jika nilai Asymp. Sig (2-tailed) > 0,05 maka terima $\mathrm{H}_{0}$ artinya data pretest berasal dari populasi yang berdistribusi secara normal. Hasil output KolmogorovSmirnov (KS-21). Hasilnya menunjukkan uji normalitas pretest pada kelas kontrol dan kelas eksperimen dengan taraf signifikan $(\alpha)$ 0,05 dan diperoleh nilai Asymp. Sig (2-tailed) untuk kelas kontrol 0,11>0,05 dan nilai Asymp. Sig (2-tailed) pada kelas eksperimen adalah 0,20>0,05 sehingga pada masing-masing kelas diperoleh keputusan terima $\mathrm{H}_{0}$ yang artinya data berasal dari data yang berdistribusi normal. Karena data berdistribusi normal, maka selanjutnya dilakukan uji homogenitas.

Uji homogenitas menunjukan nilai based on mean pada output Levene test $0,110>0,05$ maka diambil keputusan terima $\mathrm{H}_{0}$. Hal ini berarti data pretest berasal dari varian yang homogen. Data pretest memenuhi uji prasyarat untuk uji statistik parametrik, maka dapat diambil keputusan untuk melakukan uji komparatif menggunakan uji-t independent 2 sample. Uji-t Independent 2 sample ini bertujuan untuk mengetahui perbedaan data pretest kelas kontrol dan kelas eksperimen. Hasil uji-t data pretest kelas kontrol dan kelas eksperimen tertera pada tabel 1 berikut.

Tabel 1. Uji t Data Pretest

\begin{tabular}{lllll}
\hline $\begin{array}{l}\text { Jenis } \\
\text { data }\end{array}$ & $\begin{array}{l}\text { Sig. } \\
(2- \\
\text { tailed })\end{array}$ & A & Keputusan & Keterangan \\
\hline Pretest & 0,235 & 0,05 & Terima $\mathrm{H}_{0}$ & $\begin{array}{l}\text { Tidak } \\
\text { berbeda } \\
\text { signifikan }\end{array}$ \\
\hline
\end{tabular}

Pada Tabel 1, dapat diketahui bahwa nilai Sig. (2-tailed) ujit-t independent 2 sample untuk data pretest kelas kontrol dan ekperimen adalah 0,235>0,05 dengan keputusan terima $\mathrm{H}_{0}$ yang artinya tidak terdapat perbedaan yang signifikan antara pretest kelas kontrol dan pretest kelas eksperimen. Hal ini menunjukkan bahwa siswa pada kelas kontrol dan kelas eksperimen mempunyai pengetahuan awal yang sama pada materi sistem pencernaan manusia.

\section{b) Analisis Data Postest}

Dari data penelitian yang dikumpulkan pada bulan januari 2020 di XI MIA SMA Nurul Falah Pekanbaru didapatkan hasil Posttest sebagai berikut:

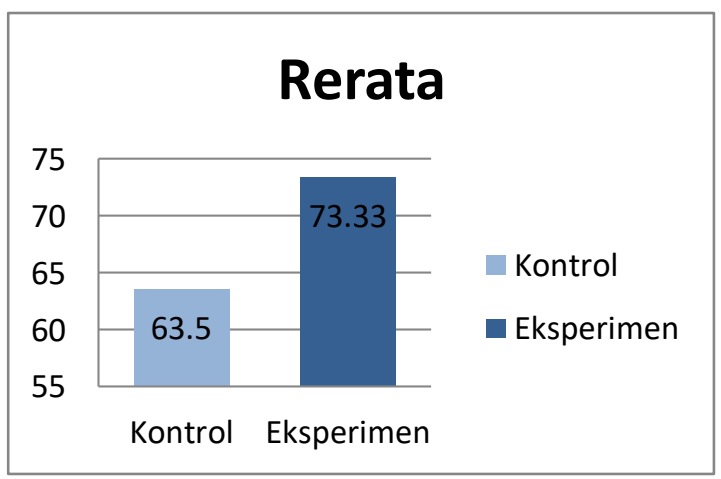

Gambar 2. Data Posttest

Pada Gambar 2 dapat dilihat bahwa rerata kelas eksperimen lebih tingi dari pada kelas kontrol. Kelas eksperimen 73,33 sedangkan kelas kontrol 63,5.

Uji hipotesis data posttest dilakukan setelah dilakukan terlebih dahulu dilakukan uji prasyarat berupa normalitas dan homogenitas. Jika nilai Asymp. Sig (2tailed) $>0,05$ maka terima $\mathrm{H}_{0}$ yang artinya data posttest berasal dari data yang berdistribusi normal.

Berdasar uji ditemukan bahwa keputusan yang didapat pada uji normalitas data posttest adalah terima $\mathrm{H}_{0}$. Karena nilai Asymp. Sig (2-tailed) pada kelas kontrol adalah 0,067 dan pada kelas eksperimen 0,131. Nilai Asymp. Sig (2tailed) dari kedua kelas ini baik kontrol ataupun eksperimen lebih besa dari nilai signifikansi $(\alpha) \quad 0,05$ maka dapat disimpulkan bahwa data posttest kelas eksperimen dan kontrol berasal dari data berdistribusi secara normal. Karena data berdistribusi normal, maka selanjutnya 
dilakukan uji homogenitas. Uji homogenitas varian data posstest menggunakan Levene test. hasil uji homogenitas didapat nilai signifikan Based on timed mean adalah 0,87 keputusan yang diambil adalah terima $\mathrm{H}_{0}$ karena $0,87>0,05$ yang artinya data posttest kelas kontrol dan kelas eksperimen berasal dari varian yang homogen.

Karena data berdistribusi secara normal dan homogen maka selanjutnya dapat dilakukan uji hipotesis komparatif Uji-t independent 2 samples. Uji hipotesis ini berguna untuk mengetahui apakah data posttest kelas kontrol dan eksperimen berbeda signifikan atau tidak. Hasil uji-t pada data posttest kelas kontrol dan eksperimen dapat dilihat pada Tabel 2 dibawah ini:

Tabel 2. Uji t Data Postest

\begin{tabular}{lllll}
\hline Jenis & $\begin{array}{l}\text { Sig. } \\
\text { data }\end{array}$ & A & Keputusan & Keterangan \\
& tailed $)$ & & & \\
\hline Posttest & 0,00 & 0,05 & ${\text { Tolak } \mathrm{H}_{0}}$ & $\begin{array}{l}\text { berbeda } \\
\text { signifikan }\end{array}$ \\
\hline
\end{tabular}

Tabel 2 di atas menunjukkan nilai Sig. (2-tailed) ujit-t independent 2 sample untuk data posttest kelas kontrol dan ekperimen adalah $0,00<0,05$ dengan keputusan tolak $\mathrm{H}_{0}$ yang artinya terdapat perbedaan yang signifikan antara posttest kelas kontrol dan pretest kelas eksperimen. Hal ini menunjukkan bahwa siswa pada kelas kontrol dan kelas eksperimen mempunyai pengetahuan akhir yang berbeda pada materi sistem pencernaan manusia.

\section{b. Analisis data N-Gain}

Berikut ini merupakan hasil N-Gain pada kelas kontrol maupun eksperimen yang direkapitulasi pada Tabel 3 dibawah ini:
Tabel 3. Rekapitulasi Hasil N-Gain Kelas Kontrol dan Eksperimen

\begin{tabular}{|c|c|c|c|c|c|}
\hline \multirow[t]{2}{*}{ Kelas } & \multirow[t]{2}{*}{$\mathbf{N}$} & \multicolumn{3}{|c|}{ N-Gain } & \multirow{2}{*}{$\begin{array}{l}\text { Rerata } \\
\text { N- } \\
\text { Gain }\end{array}$} \\
\hline & & $\begin{array}{l}\text { Nilai } \\
\text { ideal }\end{array}$ & $\begin{array}{l}\text { Nilai } \\
\text { minimum }\end{array}$ & $\begin{array}{l}\text { Nilai } \\
\text { maksimum }\end{array}$ & \\
\hline Kontr & 20 & 1,00 & 0,35 & 0,68 & 0,48 \\
\hline Eksperimen & 21 & 1,00 & 0,44 & 0,88 & 0,61 \\
\hline
\end{tabular}

Berdasarkan data yang diperoleh pada Tabel 3 di atas diketahui bahwa nilai maksimum, nilai minimum, dan rerata nilai N-Gain pada kelas eksperimen lebih tinggi dibandingkan dengan kelas kontrol. Rerata kelas eksperimen 0,61 sedangkan kontrol hanya 0,48 .

Berikut ini merupakan data hasil $\mathrm{N}$ Gain persiswa pada kelas kontrol dan kelas eksperimen.

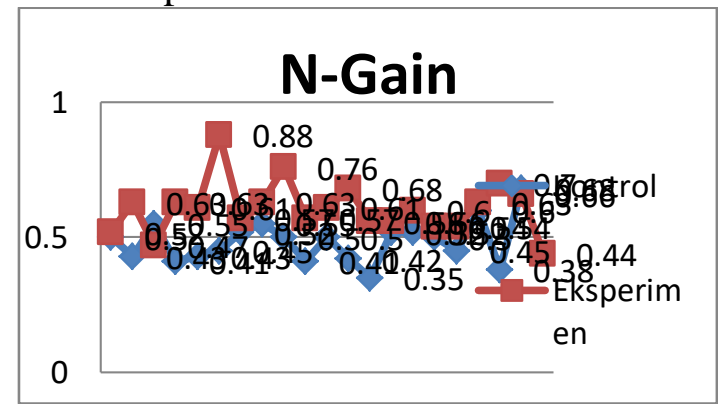

Gambar 3.Nilai N-Gain Siswa

Data N-Gain yang telah didapat kemudian dianalisis dengan melakukan uji normalitas, homogenitas, dan uji hipotesis komparatif. Uji normalitas data menggunakan Kolmogorov-smirnov (KS21). Berdasarkan Tabel 28 di dapat hasil uji normalitas $\mathrm{N}$-Gain pada kelas kontrol didapatkan nilai Asymp. Sig (2-tailed) untuk kelas kontrol adalah 0,200>0,05 dan Asymp. Sig (2-tailed) untuk kelas eksperimen adalah 0,14>0,05. Sehingga pada masing-masing kelas diperoleh kepurusan terima $\mathrm{H}_{0}$ yang artinya data berasal dari populasi yang berdistribusi normal, selanjutnya dilakukan uji homogenitas data $N$-Gain.

Hasil uji homogenitas data $N$-Gain, nilai Based On Trimmed Mean adalah $0,68>0,05$ maka diambil keputusan terima $\mathrm{H}_{0}$ yang artinya data berasal dari varian yang homogen. Karena data 
berdistribusi normal dan homogen maka selanjutnya dilakukan uji hipotesis kompratatif dengan uji-t. Hasil uji-t data N-Gain dapat di lihat pada Tabel 30. di bawah ini.

Tabel 4. Rekapitulasi Hasil uji-t data N-Gain

\begin{tabular}{ccccl}
\hline Jenis & $\begin{array}{c}\text { Sig. (2- } \\
\text { tailed) }\end{array}$ & A & Keputusan & Keterangan \\
\hline$N-$ & 0,00 & 0,05 & Tolak $\mathrm{H}_{0}$ & $\begin{array}{l}\text { Berbeda } \\
\text { signifikan }\end{array}$ \\
Gain & & & & \\
\hline
\end{tabular}

Berdasarkan Tabel 4 di atas diperoleh nilai Sig. (2-tailed) data $\mathrm{N}$-Gain yaitu $0,00<0,05$, keputusan yang diperoleh adalah tolak $\mathrm{H}_{0}$ yang artinya terdapat perbedaan yang signifikan antara $N$-Gain kelas kontrol dan eksperimen.

\section{Motivasi}

a) Analisis data pretest Angket Motivasi

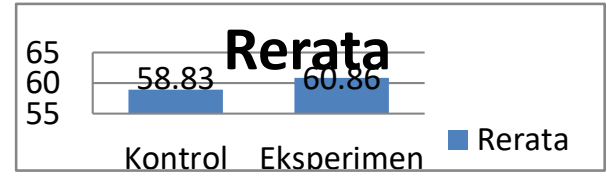

Gambar 4. Rerata angket pretest

Gambar 4 menunjukkan bahwa rerata angket kelas eksperimen 60,86 dan rerata kelas kontrol 58,83. Eksperimen lebih tinggi dari pada kontrol.

Hasil Pengujian normalitas data pretest dilakukan dengan menggunakan uji Kolmogorov-Smirnov (KS-21). Jika data berdistribusi normal maka selanjutnya dilakukan uji homogenitas lalu dilanjutkan dengan uji t. Pada uji normalitas data pretest Nilai Asymp. Sig (2-tailed) yang diperoleh dibandingkan dengan nilai $(\alpha)$ 0,05. Jika nilai Asymp. Sig (2-tailed) $>0,05$ maka terima $\mathrm{H}_{0}$ artinya data pretest berasal dari populasi yan berdistribusi secara normal.

Hasil uji normalitas pretest angket pada kelas kontrol dan kelas eksperimen dengan taraf signifikan $(\alpha)$ 0,05 dan diperoleh nilai Asymp. Sig (2-tailed) untuk kelas kontrol $0,200>0,05$ dan nilai Asymp. Sig (2-tailed) pada kelas eksperimen adalah 0,053>0,05 sehingga pada masing-masing kelas diperoleh keputusan terima $\mathrm{H}_{0}$ yang artinya data berasal dari data yang berdistribusi normal. Karena data berdistribusi normal, maka selanjutnya dilakukan uji homogenitas.

Uji Homogenitas data pretest menggunakan Levene test. Bila data memenuhi uji prasarat untuk statistic parametrik (berdistribusi normal dan homogen) maka dapat dilakukan uji lanjutan yaitu uji-t (t-test). Jika data tidak memenuhi syarat untuk uji prasyarat (tidak berdistribusi secara normal dan tidak homogen) maka dapat dilakukan uji lanjutan menggunakan U-mann Whitney test untuk uji nonprametrik.

Hasil uji homogenitas menunjukkan nilai based on mean pada output Levene test 0,32>0,05 maka diambil keputusan terima $\mathrm{H}_{0}$. Hal ini berarti data pretest berasal dari varian yang homogen. Data pretest memenuhi uji prasyarat untuk uji statistik parametrik, maka dapat diambil keputusan untuk melakukan uji komparatif menggunakan uji-t independent 2 sample. Uji-t Independent 2 sample ini bertujuan untuk mengetahui perbedaan data pretest kelas kontrol dan kelas eksperimen. Hasil uji-t data pretest kelas kontrol dan kelas eksperimen tertera pada tabel berikut.

\begin{tabular}{|c|c|c|c|c|}
\hline & Tabe & $H a$ & $U j i-t D$ & rete \\
\hline $\begin{array}{l}\text { Jenis } \\
\text { data }\end{array}$ & $\begin{array}{l}\text { Sig. } \\
(2- \\
\text { tailed } \\
)\end{array}$ & $\mathbf{A}$ & $\begin{array}{l}\text { Keputusa } \\
\text { n }\end{array}$ & $\begin{array}{l}\text { Keteranga } \\
\mathrm{n}\end{array}$ \\
\hline $\begin{array}{l}\text { Pretes } \\
t\end{array}$ & 0,060 & $\begin{array}{l}0,0 \\
5\end{array}$ & Terima $\mathrm{H}_{0}$ & $\begin{array}{l}\text { Tidak } \\
\text { berbeda } \\
\text { signifikan }\end{array}$ \\
\hline
\end{tabular}

Tabel 5 di atas menunjukkan nilai

Sig. (2-tailed) ujit-t independent 2 sample untuk data pretest kelas kontrol dan ekperimen adalah 0,060>0,05 dengan keputusan terima $\mathrm{H}_{0}$ yang artinya tidak terdapat perbedaan yang signifikan antara pretest kelas kontrol dan pretest kelas eksperimen. Hal ini menunjukkan bahwa Lectura: Jurnal Pendidikan, Vol.11 No. 1, Februari 2020 
siswa pada kelas kontrol dan kelas eksperimen mempunyai motivasi belajar awal yang sama pada materi sistem pencernaan manusia.

\section{b) Analisis Data Postest}

Berdasarkan hasil penelitian yang telah dilaksanakan, didapatkan hasil Posttest angket sebagai berikut.

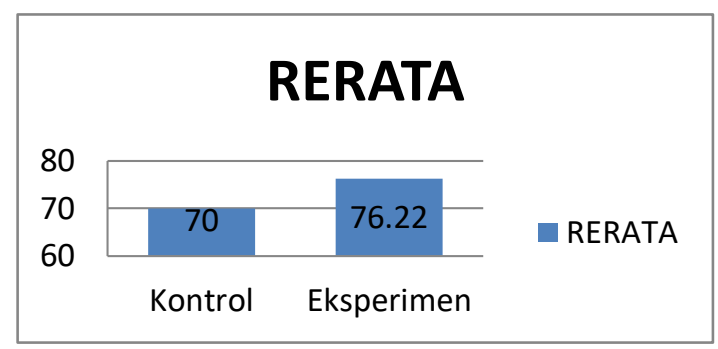

Gambar 5. Rerata postest angket

Pada Gambar 5, dapat dilihat bahwa rerata ekperimen 76,22 sedangkan kelas kontrl 70,0. Sebelum dilakukan uji hipotesis pada data posttest maka terlebih dahulu dilakukan uji normalitas dan homogenitas pada data posttest. Uji normalitas varian data posttest menggunakan Kolmogorov-Smirnov (KS21) nilai Asymp. Sig (2-tailed) dibandingkan dengan nilai $(\alpha) 0,05$. Jika nilai Asymp. Sig (2-tailed) > 0,05 maka terima $\mathrm{H}_{0}$ yang artinya data posttest berasal dari data yang berdistribusi normal.

Uji normalitas data posttest adalah terima $\mathrm{H}_{0}$. Karena nilai Asymp. Sig (2tailed) pada kelas kontrol adalah 0,20 dan pada kelas eksperimen 0,15 yang jika dibandingkan dengan nilai taraf signifikansi ( $\alpha$ ) 0,05 maka nilai Asymp. Sig (2-tailed pada kelas kontrol dan eksperimen adalah >0,05. Maka dapat disimpulkan bahwa data posttest kelas eksperimen dan kontrol berasal dari data berdistribusi secara normal.

Karena data berdistribusi normal, maka selanjutnya dilakukan uji homogenitas. Uji homogenitas varian data posstest menggunakan Levene test. Hasil output Levene test didapat nilai signifikan Based on timed mean adalah 0,80 keputusan yang diambil adalah terima $\mathrm{H}_{0}$ karena $0,80>0,05$ yang artinya data posttest angket kelas kontrol dan kelas eksperimen berasal dari varian yang homogen.

Karena data berdistribusi secara normal dan homogen maka selanjutnya dapat dilakukan uji hipotesis komparatif Uji-t independent 2 samples. Uji hipotesis ini berguna untuk mengetahui apakah data posttest angket kelas kontrol dan eksperimen berbeda signifikan atau tidak. Hasil uji-t pada data posttest kelas kontrol dan eksperimen dapat dilihat pada Tabel 6 di bawah ini.

Tabel 6. Hasil Uji-t data Posttest

\begin{tabular}{lllll}
\hline Jenis & Sig. & $\alpha$ & Keputusan & Keterangan \\
data & $(2-$ & & & \\
& tailed $)$ & & & \\
\hline Posttest & 0,00 & 0,05 & Tolak $\mathrm{H}_{0}$ & $\begin{array}{l}\text { berbeda } \\
\text { signifikan }\end{array}$ \\
\hline
\end{tabular}

Tabel 6 menunjukkan nilai Sig. (2tailed) ujit-t independent 2 sample untuk data posttest kelas kontrol dan ekperimen adalah 0,00 $<0,05$ dengan keputusan tolak $\mathrm{H}_{0}$ yang artinya terdapat perbedaan yang signifikan antara posttest angket kelas kontrol dan pretest kelas eksperimen. Hal ini menunjukkan bahwa siswa pada kelas kontrol dan kelas eksperimen mempunyai motivasi belajar akhir yang berbeda pada materi sistem pencernaan manusia.

\section{c) Analisis data N-Gain}

Berikut ini merupakan hasil $\mathrm{N}$ Gain pada kelas kontrol maupun eksperimen yang direkapitulasi pada Tabel 39 dibawah ini.

Tabel 7. Rekapitulasi Hasil N-Gain Angket Kelas Kontrol dan Eksperimen

\begin{tabular}{|c|c|c|c|c|c|}
\hline \multirow[t]{2}{*}{ Kelas } & \multirow[t]{2}{*}{$\mathbf{N}$} & \multicolumn{3}{|c|}{ N-Gain } & \multirow{2}{*}{$\begin{array}{l}\text { Rerata } \\
\text { N- } \\
\text { Gain }\end{array}$} \\
\hline & & $\begin{array}{l}\text { Nilai } \\
\text { ideal }\end{array}$ & $\begin{array}{l}\text { Nilai } \\
\text { minimum }\end{array}$ & $\begin{array}{l}\text { Nilai } \\
\text { maksimum }\end{array}$ & \\
\hline Kontrol & 20 & 1,50 & 0,12 & 0,39 & 0,27 \\
\hline Eksperimen & 21 & 1,50 & 0,17 & 0,53 & 0,39 \\
\hline
\end{tabular}


Berdasarkan data yang diperoleh pada Tabel 7 di atas, diketahui bahwa nilai maksimum, nilai minimum, dan rerata nilai N-Gain pada kelas eksperimen lebih tinggi dibandingkan dengan kelas kontrol. Perbandingan hasil data rerata $\mathrm{N}$-Gain kelas eksperimen dan kontrol dapat dilihat pada diagram batang berikut.

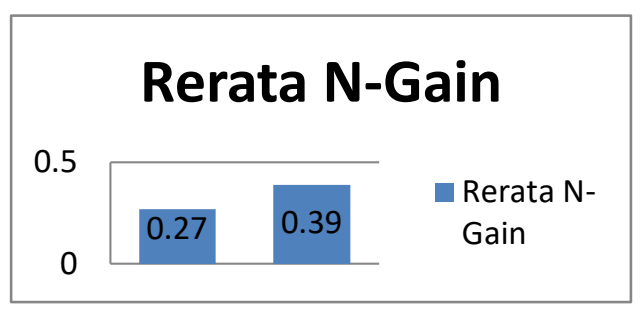

Gambar 6. Rerata N Gain

Data N-Gain yang telah didapat kemudian dianalisis dengan melakukan uji normalitas, homogenitas, dan uji hipotesis komparatif. Jika data berdistribusi normal maka dan mempunyai varian yang homogen maka uji yang digunakan statistik parametrik yaitu uji-t, tetapi apabila data tidak berdistribusi normal dan homogen maka digunakan statistik non parametrik dengan menggunakan Uji Mann-Whitney. Uji normalitas data menggunakan Kolmogorov-smirnov (KS21).

Hasil uji normalitas $N$-Gain pada kelas kontrol didapatkan nilai Asymp. Sig (2-tailed) untuk kelas kontrol adalah 0,20 > 0,05 dan Asymp. Sig (2-tailed) untuk kelas eksperimen adalah 0,20>0,05. Sehingga pada masing-masing kelas diperoleh keputusan terima $\mathrm{H}_{0}$ yang artinya data berasal dari populasi yang berdistribusi normal, selanjutnya dilakukan uji homogenitas data $N$-Gain. Hasil uji homogenitas data N-Gain kelas kontrol menunjukkan nilai Based On Trimmed Mean adalah 0,18>0,05 maka diambil keputusan terima $\mathrm{H}_{0}$ yang artinya data berasal dari varian yang homogen. Karena data berdistribusi normal dan homogen maka selanjutnya dilakukan uji hipotesis kompratatif dengan uji-t. Hasil Lectura: Jurnal Pendidikan, Vol.11 No. 1, Februari 2020 uji-t data N-Gain dapat di lihat pada tabel 40. di bawah ini.

Tabel 8. Rekapitulasi Hasil uji-t data N-

\begin{tabular}{|c|c|c|c|c|}
\hline \multicolumn{5}{|c|}{ Gain } \\
\hline Jenis & $\begin{array}{l}\text { Sig. (2- } \\
\text { tailed) }\end{array}$ & $\mathbf{A}$ & Keputusan & Keterangan \\
\hline $\begin{array}{c}N- \\
\text { Gain }\end{array}$ & 0,00 & 0,05 & Tolak $\mathrm{H}_{0}$ & $\begin{array}{l}\text { Berbeda } \\
\text { signifikan }\end{array}$ \\
\hline
\end{tabular}
diperoleh nilai Sig. (2-tailed) data $N$-Gain yaitu $0,00<0,05$, keputusan yang diperoleh adalah tolak $\mathrm{H}_{0}$ yang artinya terdapat perbedaan yang signifikan antara $N$-Gain motivasi kelas kontrol dan eksperimen.

\section{Pembahasan}

Berdasarkan hasil pretest yang telah diuji dengan uji normalitas dan uji homogenitas, data pretest pada kelas eksperimen dan kontrol berasal dari data populasi yang berdistribusi normal dan variannya homogen. Rerata pretest pada kelas eksperimen adalah 29,33 dan kelas eksperimen adalah 32,06. Hasil uji komparatif terhadap data pretest kelas kontrol dan kelas eksperimen dilakukan dengan menggunakan statistik parametrik yaitu uji-t independen 2 samples. Hasil uji-t diperoleh nilai sig. (2-tailed) adalah $0,235>0,05$ keputusan terima $\mathrm{H}_{0}$ artinya tidak terdapat perbedaan yang signifikan antara nilai pretest kelas kontrol dan kelas eksperimen. Tidak adanya perbedaan yang signifikan ini menunjukkan bahwa kemampuan awal kedua kelas pada materi sistem pencernaan adalah hampir sama. Pengetahuan awal siswa merupakan salah satu hal yang penting dalam menentukan hasil belajar siswa. Sejalan dengan pendapat Rustaman (2003), yang menyatakan bahwa tidak hanya lingkungan dan kondisi belajar yang menentiukan hasil belajar siswa tetapi juga sangat ditentukan oleh pengetahuan awal yang dimiliki siswa. 
Data posttest pada kelas kontrol memiliki rerata 63,5 sedangkan rerata posttest pada kelas eksperimen adalah 73,3. Pengujian data posttest pada kelas kontrol dan eksperimen dilakukan dengan menggunakan statistik parametrik yaitu uji-t independen 2 samples. Hasil uji-t posttest diperoleh nilai sig (2 tailed) adalah $0,00<0,05$ keputusan tolak $\mathrm{H}_{0}$ artinya terdapat perbedaan yang signifikan antara nilai posttest kelas eksperimen dan kelas kontrol, hal ini menunjukkan kedua kelas memiliki hasil belajar akhir yang berbeda pada materi sistem pencernaan. Adanya perbedaan antara nilai akhir kelas eksperimen dan kontrol ini disebabkan oleh berbedanya perlakuan yang diberikan berupa metode pengajaran yang digunakan oleh guru. Hal ini sejalan dengan pendapat Pupuh \& Sobry (2009) yang menyatakan bahwa makin tepat metode yang digunakan guru dalam mengajar, maka makin efektif pula pencapaian tujuan pembelajaran.

Nilai $N$-Gain menunjukkan terjadinya peningkatan hasil belajar siswa yang baik pada materi sistem pencernaan. Rerata $N$-Gain pada kelas kontrol 0,486 kategori sedang dan rerata $\mathrm{N}$-Gain pada kelas eksperimen 0,612 kategori sedang, berdasarkan kategori N Gain (Meltzer, 2002). Hal ini terjadi karena adanya perbedaan perlakuan antara kelas kontrol dan kelas eksperimen. Pada kelas kontrol menggunakan metode pembelajaran langsung (Direct Instruction) sedangkan pada kelas eksperimen menggunakan $e$ learning dengan bantuan aplikasi google classroom. Uji-t dari data $N$-Gain dengan taraf signifikansi $(\alpha)$ 0,05 diperoleh nilai Sig. (2-tailed) sebesar 0,00. Keputusan yang diperoleh adalah tolak $\mathrm{H}_{0}$ yang artinya terdapat perbedaan yang signifikan antara $N$-Gain kelas kontrol dan kelas eksperimen pada materi sistem pencernaan. Meningkatnya hasil belajar siswa dipengaruhi oleh pemilihan metode pembelajaran dan media yang tepat.
Dimana Google Classroom sebagai media pembelajaran sangat berperan penting dalam mendukung terlaksananya $e$ learning. Pendapat ini sejalan dengan Jumaeroh \& Anggun (2019) yang menyatakan bahwa kedudukan media pembelajaran ada dalam metode pembelajaran. Ibrahim dan Siti (2014) menemukan bahwa e-learning mampu meningkatkan prestasi belajar siswa

Fungsi utama dari media pembelajaran adalah sebagai alat bantu mengajar untuk menunjang penggunaan metode pembelajaran yang digunakan oleh guru. Media pembelajaran untuk masa sekarang ini tidaklah sedikit khususnya dalam dunia Teknologi Informasi dan Komunikasi (TIK) yang sering disebut dengan e-learning ini membawa pengaruh transformasi pendidikan konvensional ke dalam bentuk digital, baik isi maupun sistemnya. Aplikasi juga dapat digunakan oleh siapa saja dan dapat diakses dimana saja sehingga dapat menghemat waktu (Nirfayanti \& Nurbaeti, 2019). Hal ini menunjukkan bahwa kemampuan teknologi sebagai bagian dari lingkungan masyarakat seperti sekarang ini dapat memberikan dampak bagi hasil belajar dan motivasi siswa. Semakin tinggi motivasi belajar siswa maka akan memberikan pengaruh yang besar pula pada hasil belajar siswa. Hal ini sejalan dengan pendapat Doni \& Siti (2014) yang menyatakan bahwa melakukan aktivitas dengan motivasi yang besar dan kuat akan memperoleh hasil yang maksimal, sebaliknya jika tidak didasari motivasi yang besar dan kuat maka akan memperoleh hasil yang minimal, hal ini berlaku pada semua bidang termasuk pendidikan.

Meningkatnya hasil belajar pada kelas eksperimen disebabkan karena penggunaan e-learning dengan google classroom dalam pembelajarannya. Sesuai dengan pendapat Rusman (2012) yang 
menyatakan bahwa pembelajaran $e$ learning memiliki kelebihan yaitu pembelajarannya yang dilakukan bersifat individual, jadi pelajar dapat belajar sesuai dengan karakteristik dan langkahnya sendiri. Penggunaan Google classroom sebagai media pembelajaran juga mendukung meningkatnya motivasi belajar siswa, karena dengan google classroom pengajar dipermudah dalam distribusi tugas, sumit, dan menilai tugastugas sehingga siswa pun lebih mudah dalam mengakses mengerjakan tugas yang diberikan.

Motivasi belajar diukur menggunakan angket tertutup yang menggunakan skala likert dengan jawaban berupa SS (Sangat Setuju), S (Setuju), KS (Kurang Setuju), TS (Tidak Setuju), dan STS (Sangat Tidak Setuju). Angket motivasi diberikan pada kelas kontrol dan eksperimen. Hasil angket motivasi awal dari kedua kelas yang diteliti dianalisis secara kuantitatif prasyarat berupa uji normalitas, homogenitas, dan uji-t.

Hasil uji data pretest angket motivasi belajar menunjukkan nilai Sig. (2-tailed) ujit-t independent 2 sample untuk data pretest kelas kontrol dan ekperimen adalah 0,060>0,05 dengan keputusan terima $\mathrm{H}_{0}$ yang artinya tidak terdapat perbedaan yang signifikan antara pretest kelas kontrol dan pretest kelas eksperimen. Hal ini menunjukkan bahwa siswa pada kelas kontrol dan kelas eksperimen mempunyai motivasi belajar awal yang sama pada materi sistem pencernaan manusia. Setelah melakukan proses pembelajaran dan masing-masing menerima perlakuan yang berbeda, lalu selanjutnya diberi angket motivasi akhir. Hasil uji-t angket posttest didapatkan nilai Sig. (2-tailed) ujit-t independent 2 sample untuk data posttest kelas kontrol dan ekperimen adalah $0,00<0,05$ dengan keputusan tolak $\mathrm{H}_{0}$ yang artinya terdapat perbedaan yang signifikan antara posttest motivasi kelas kontrol dan posttest motivasi kelas eksperimen. Hal ini menunjukkan bahwa siswa pada kelas kontrol dan kelas eksperimen mempunyai motivasi belajar akhir yang berbeda pada materi sistem pencernaan manusia.

Meningkatnya motivasi belajar dan hasil belajar pada kelas eksperimen disebabkan karena penggunaan e-learning dengan google classroom dalam pembelajarannya. Pusvyta (2015) mengungkapkan bahwa belajar denfgan e learning siswa semakin termotivasi. Sesuai dengan pendapat Rusman (2012) yang menyatakan bahwa pembelajaran $e$ learning memiliki kelebihan yaitu pembelajarannya yang dilakukan bersifat individual, jadi pelajar dapat belajar sesuai dengan karakteristik dan langkahnya sendiri. Rikizaputra dan Wulandari (2017) juga menemukan bahwa motivasi berkaitan erat dengan hasil belajar yang dipengaruhi oleh metode yang digunakan.

Penggunaan Google classroom sebagai media pembelajaran juga mendukung meningkatnya motivasi belajar siswa, karena dengan google classroom pengajar dipermudah dalam distribusi tugas, sumit, dan menilai tugastugas sehingga siswa pun lebih mudah dalam mengelaborasi dan menyelesaikan pekerjaan yang diberikan. Nirfayanti \& Nurbaeti, (2019) menyatakan bahwa aplikasi dapat dipakai oleh siapapun dan dapat diakses dimanapun sehingga berdampak pada efektifitas dan efisiensi waktu

Adanya peningkatan aktifitas belajar siswa sejalan dengan meningkatnya motivasi siswa dalam mengikuti pelajaran, dimana aktfitas dan motivasi ini sangat mempengaruhi hasil belajar siswa. Hal yang sama juga dikemukakan oleh Nashar (2004) yang menyatakan adanya kebiasaan siswa untuk melakukan kegiatan pembelajaran yang didorong oleh keinginan untuk mendapatkan prestasi belajar sebaik mungkin. 


\section{KESIMPULAN}

Hasil penelitian yang telah dilakukan, didapatkan kesimpulan bahwa penggunaan e-learning dengan google classroom berpengaruh terhadap hasil belajar dan motivasi siswa pada materi sistem pencernaan di kelas XI MIA SMA Nurul Falah Pekanbaru Tahun Ajaran 2019/2020. Peningkatan hasil belajar dan motivasi siswa ini dapat dilihat dari hasil $\mathrm{N}$-Gain kelas eksperimen yang lebih besar dari nilai $N$-Gain kelas kontrol, hasil uji-t yang berbeda signifikan pada hasil belajar siswa, adanya perbedaan motivasi siswa, dan juga adanya peningkatan aktifitas siswa. Maka penggunaan e-learning dengan google classroom ini dapat diterapkan sebagai metode yang tepat dalam pembelajaran masa kini.

\section{DAFTAR PUSTAKA}

Anderson, L.W., \& Krathwohl D.R. 2010. Kerangka Landasan untuk Pembelajaran, Pengajaran dan Asesmen (Revisi Taksonomi Pendidikan Bloom). Yogyakarta: Pustaka Pelajar.

Anderson, T. 2008. The Theory and Practice of Online Learning. Canada: Athabasca University.

Departemen Pendidikan Nasional (Depdiknas). 2004. Kerangka dasar kurikulum 2004. Depdiknas. Jakarta.

Dimyati \& Mudjiono. 2013. Belajar Dan Pembelajaran. Jakarta: Rineka Cipta.

Doni I.S., \& Siti P.S. 2014. Pengaruh Penggunaan E-Learning Terhadap Hasil Belajar dan Motivasi dan Prestasi Belajar Matematika Siswa SD Negeri Tahunan Yogyakarta. Jurnal Prima Edukasia, 1(2): 66-79.
Hamalik, O. 2011. Proses Belajar Mengajar. Jakarta: Bumi Aksara.

Ibrahim S.B., \& Siti P.S. 2014. Pengaruh Penggunaan E-learning Terhadap Motivasi dan Prestasi Belajar Matematika Siswa SDN Tahunan Yogyakarta. Jurnal Prima Edukasia 1(2): 66-79.

Jumaeroh S \& Anggun Z. 2019. Pengaruh Media Edmodo Terhadap Hasil Belajar IPA Pada Materi Tekanan dengan model Discovery Learning. Thabiea: Journal of Natural Science Teaching 2(2):118-122.

Meltzer D.E. 2002. "The Relationship Between Matematics Preparation and Conceptual Learning Gains in physicn: A possible "hidden variable" in diagnostic pretest score". American Journal of Physics. 70 (12): 1259-1268.

Nashar. 2004. Peranan Motivasi dan Kemampuan Awal. Jakarta: Delia Press

Nirfayanti., \& Nurbeti. 2019. Pengaruh Media Pembelajaran Google Classroom dalam Pembelajaran Analisis Real Terhadap Motivasi Belajar Mahasiswa. Proximal: Jurnal penelitian matematika dan pendidikan matematika.. 1 (2) : 5059.

Prawiradilaga, D. S. 2015. Prinsip Desain Pembelajaran. Jakarta: Kencana.

Pupuh, F \& M. Sobry. 2009. Strategi Belajar Mengajar: Strategi Mewujudkan Pembelajaran Bermakna Melalui Penanaman Konsep Umum \& Konsep Islami. Bandung: Refika Aditama. 
Pusvyta S. 2015. Memotivasi belajar dengan menggunakan e-learning. Jurnal Ummul Qura, 2 (6): 20-35.

Rikizaputra dan Wulandari, F. (2017). Hubungan Antara Motivasi dan Persepsi Siswa Terhadap Kinerja Guru Dengan Hasil Belajar Biologi Siswa Kelas X SMAN 13 Pekanbaru Tahun Ajaran 2016/2017. Jurnal Bio Lectura 04 (02), 131-145. https://ejurnal.unilak.ac.id/index.p hp/BL/article/view/995

Rusman. 2012. Belajar dan Pembelajaran berbasis Komputer Mengembangkan profesionalisme Guru abad 21. Bandung: Alfabeta.

Rustaman, Y.N. (2003). Strategi Belajar Mengajar Biologi. Common Text Book JICA Edisi Revisi. Bandung: Bilogi FPMIPA UPI.

Sugihartono. 2007. Psikologi Pendidikan. Yogyakarta: UNY Press. 